\title{
The Vicia faba Leghemoglobin Gene VfLb29 Is Induced in Root Nodules and in Roots Colonized by the Arbuscular Mycorrhizal Fungus Glomus fasciculatum
}

\author{
Martin Frühling, ${ }^{1}$ Hélène Roussel, ${ }^{2}$ Vivienne Gianinazzi-Pearson, ${ }^{2}$ Alfred Pühler, ${ }^{1}$ and Andreas M. \\ Perlick ${ }^{1}$ \\ ${ }^{1}$ Universität Bielefeld, Lehrstuhl für Genetik, Postfach 100131, D-33501 Bielefeld, Germany; ${ }^{2}$ Station de \\ Génétique et d'Amélioration des Plantes, INRA, BV 1540, F-21034 Dijon cédex, France \\ Received 11 July 1996. Accepted 30 October 1996.
}

To investigate similarities between symbiotic interactions of broad bean (Vicia faba) with rhizobia and mycorrhizal fungi, plant gene expression induced by both microsymbionts was compared. We demonstrated the exclusive expression of 19 broad bean genes, including VfENOD2, VfENOD5, VfENOD12 and three different leghemoglobin genes, in root nodules. In contrast, the leghemoglobin gene VfLb29 was found to be induced not only in root nodules, but also in broad bean roots colonized by the mycorrhizal fungus Glomus fasciculatum. In uninfected roots, none of the 20 nodulin transcripts investigated was detectable. VfLb29 has an unusually low sequence homology with all other broad bean leghemoglobins as well as with leghemoglobins from other legumes. It can be regarded as a novel kind of leghemoglobin gene not described until now and the induction of which is common to symbiotic interactions of broad bean with both Rhizobium and a mycorrhizal fungus.

The majority of legume species can establish symbiotic associations with two important groups of rhizosphere microorganisms, bacteria of the genus Rhizobium and arbuscular mycorrhizal fungi of the order Glomales. The Rhizobium-legume interaction leads to symbiotic nitrogen fixation carried out by differentiated bacteria within a specialized plant organ, the root nodule (Brewin 1991). Root colonization by arbuscular mycorrhizal fungi increases plant biomass and enhances vigour and ecological fitness of both organisms (Harley and Smith 1983). Closer examination of root nodule formation induced by rhizobia and root colonization by arbuscular mycorrhizal fungi reveals several similarities of these two interactions. In both cases the target tissue for the symbiont is derived from the root cortex. During penetration of root tissue, the microsymbionts are separated from the host cells by plantderived cell wall material (VandenBosch et al. 1989; Perotto et al. 1989). The invasion and colonization of the plant cells is

Corresponding author: A. M. Perlick: Telefax: +49 (0)521 106 5625, Telephone: +49 (0)521 1065607

The sequence data reported will appear in the EMBL database under the accession numbers Z54157 (VfLbB), Z54158 ( $V f L b K$ ), Z54159 (VfLb49) and Z54160 (VfLb29), respectively. linked to proliferation of the microsymbiont and its development into pleomorphic intracellular forms, the bacteroids in nodules and the arbuscules in mycorrhiza. Both bacteroids and arbuscules are separated from the plant cytoplasm by a hostderived perisymbiotic membrane (Mellor 1989). The peribacteroid membrane (in nodules) and the periarbuscular membrane (in mycorrhiza) are suggested to be extended interfaces between the symbiotic partners where bidirectional exchange of metabolites takes place (Smith and Smith 1990).

The development of an effective, nitrogen-fixing symbiosis in root nodules is determined by genes from both rhizobia and their host plants. In recent years, the bacterial genetics of nodule formation and nitrogen fixation have been extensively studied (Fisher and Long 1992; Fischer 1994). An increasing number of plant genes specifically expressed in nodules, termed nodulin genes (van Kammen 1984), have been identified and subdivided into early and late nodulin genes according to the time point of their expression (Brewin 1991; Verma et al. 1992). Early nodulin genes (ENODs) are associated with organogenesis and bacterial invasion of the root nodule. In general, late nodulin gene (NOD) products are thought to be involved in nodule function and include the oxygen transporter leghemoglobin, enzymes of carbon and nitrogen metabolism, proteins located in the peribacteroid interface as well as proteins of unknown function (Delauney and Verma 1988).

In contrast, analysis of the molecular mechanisms involved in arbuscular mycorrhiza are still in their infancy mainly due to recalcitrance of the fungal partner to pure culture (Gianinazzi-Pearson et al. 1994). However, there are evidences indicating some molecular mechanisms may be common to symbiotic Rhizobium interactions. Firstly, identification of mycorrhiza-resistant $\left(\mathrm{myc}^{-}\right)$phenotypes among nonnodulating $\left(\right.$ nod $\left.^{-}\right)$genotypes of different legumes (Duc et al. 1989; Weeden et al. 1990; Bradbury et al. 1991; GianinazziPearson et al. 1991) has demonstrated that some steps in recognition or infection processes are controlled by common plant genetic determinants. On the other hand, the existence of myc $^{+}$nod $^{-}$plant mutants (Duc et al. 1989) demonstrates the involvement of different plant genes in the two types of symbiosis. Secondly, transcripts coding for some polypeptides that are immunologically cross-reactive with nodule-specific plant proteins (nodulins) have been detected in mycorrhizal roots 
(Wyss et al. 1990). Furthermore, monoclonal antibodies raised against components of the infection thread or the peribacteroid membrane in nodules localize antigenic sites in the periarbuscular interface (Gianinazzi-Pearson et al. 1990; Perotto et al. 1994; Gollotte et al. 1995). However, activation of nodulin genes induced during rhizobial infection or nodule formation has not yet been reported in mycorrhizal roots.

The aim of the present work was to obtain more information about the extent to which similarities and differences exist between arbuscular mycorrhiza and nodule symbioses. For this, we analyzed 20 broad bean (Vicia faba) nodulin genes for their induction in nodules and in broad bean roots colonized by the arbuscular mycorrhizal fungus Glomus fasciculatum. We report on the identification of one leghemoglobin transcript common to nodules and mycorrhizal roots. This transcript is compared with other broad bean leghemoglobin transcripts which are undetectable in mycorrhizal roots and implications of the findings are discussed.

\section{RESULTS}

Members of a nodule-specific broad bean cDNA library encode 20 different nodulins.

To investigate the nodule-specific gene expression in broad bean, we have constructed a nodule-specific cDNA library of approximately 700 independent cDNAs (Perlick and Pühler 1993). Following cross-hybridization experiments and sequence analysis, this library has been subdivided into 44 clone groups representing different genes activated in the root nodule. Twenty of these groups (Table 1) specify transcript sequences expressed in the nodule but not in uninfected roots (Fig. 1) and therefore code for nodulins. Searches of the GenBank database has revealed homologies for nearly all the broad bean nodulin transcripts (Table 1). In addition to four

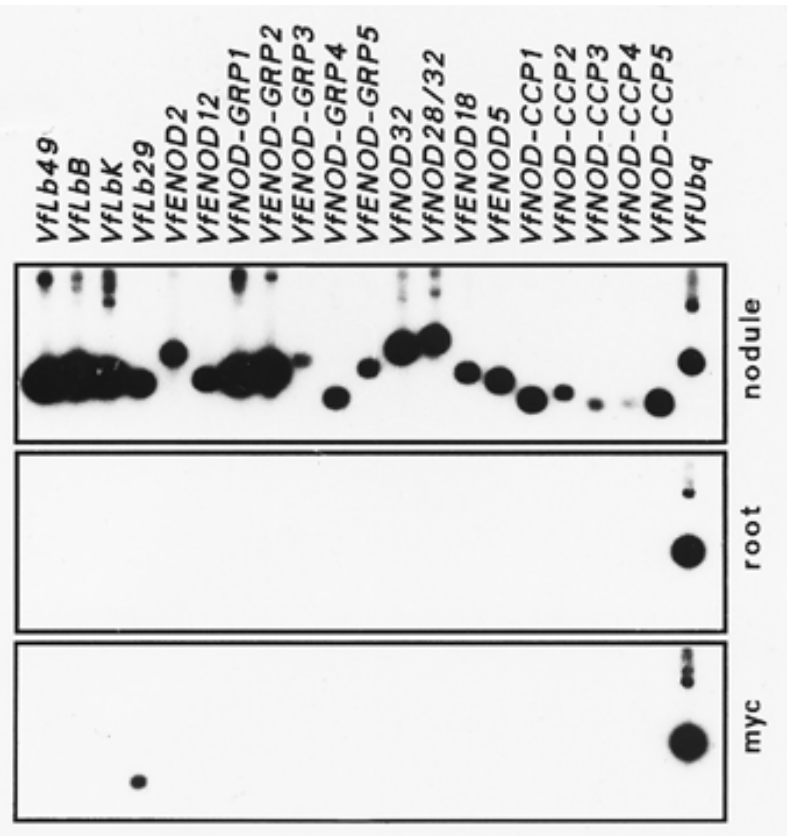

Fig. 1. Expression of broad bean nodulin transcripts in nodules, uninfected and mycorrhizal roots. EcoRI digested cDNA clones representing transcript sequences which code for broad bean nodulins (see Table 1) and for ubiquitin (VfUbq) were separated on agarose gels and blotted onto nylon membranes. Hybridizations were carried out with radioactively-labeled cDNA probes synthesized from poly $(\mathrm{A})^{+}$RNA isolated either from nodules, uninfected roots or roots colonized by Glomus fasciculatum (myc). The times of exposure for root and myc autoradiographs were adjusted according to the ubiquitin hybridization signals.

Table 1. Broad bean nodulin genes analyzed

\begin{tabular}{|c|c|c|c|c|}
\hline Broad bean gene & $\begin{array}{l}\text { cDNA clone se- } \\
\text { quenced }^{\mathrm{a}}\end{array}$ & Clone group ${ }^{b}$ & $\begin{array}{l}\text { Homologous genes or gene } \\
\text { products }\end{array}$ & References \\
\hline \multicolumn{5}{|l|}{ Leghemoglobins } \\
\hline$V f L b B$ & $150-1$ & VfNDS-B & Leghemoglobins & Perlick and Pühler 1993 \\
\hline VfLbK & $111-51$ & VfNDS-K & Leghemoglobins & Perlick and Pühler 1993 \\
\hline VfLb49 & $\mathrm{lb} 84$ & VfLb & Leghemoglobins & Perlick and Pühler 1993 \\
\hline VfLb29 & $226-1$ & VfNDS-X29 & Leghemoglobins & This study \\
\hline \multicolumn{5}{|c|}{ Proline- and glycine-rich nodulins } \\
\hline VfENOD2 & $107-68$ & VfNDS-H & ENOD2 & Perlick and Pühler 1993 \\
\hline VfENOD12 & $114-96$ & VfNDS-X7 & ENOD12 & Perlick and Pühler 1993 \\
\hline VfNOD-GRP1 & $2-7-3$ & VfNDS-F & GRPs & Perlick and Pühler 1993 \\
\hline VfENOD-GRP2 & $103-53$ & VfNDS-G & GRPs & Perlick and Pühler 1993 \\
\hline VFENOD-GRP3 & $125-71$ & VfNDS-X14 & GRPs & Küster et al. 1995 \\
\hline VfNOD-GRP4 & $163-2$ & VfNDS-X20 & GRPs & This study \\
\hline VfENOD-GRP5 & $168-2$ & VfNDS-X22 & GRPs & This study \\
\hline \multicolumn{5}{|l|}{ Other nodulins } \\
\hline VfNOD32 & $1-1-2$ & VfNDS-A & Narbonin, chitinases & Perlick et al. 1996 \\
\hline VfNOD28/32 & $6-1-27$ & VfNDS-L & $M s N O D 25$ & Küster et al. 1994 \\
\hline VfENOD18 & $70-1$ & VfNDS-X9 & & Perlick and Pühler 1993 \\
\hline VfENOD5 & $118-24$ & VfNDS-X11 & PSENOD5 & Perlick and Pühler 1993 \\
\hline \multicolumn{5}{|c|}{ Nodulins with conserved cysteine clusters } \\
\hline VfNOD-CCP1 & $182-1$ & VfNDS-J & PSENOD 3 and 14, PSNOD6 & Perlick and Pühler 1993 \\
\hline VfNOD-CCP2 & $121-79$ & VfNDS-X12 & PSENOD 3 and 14, PSNOD6 & Perlick and Pühler 1993 \\
\hline VfNOD-CCP3 & $167-1$ & VfNDS-X19 & PSENOD3 and 14, PsNOD6 & This study \\
\hline VfNOD-CCP4 & $197-1$ & VfNDS-X25 & PsENOD 3 and 14, PsNOD6 & This study \\
\hline VINOD-CCP5 & $301-1$ & VfNDS-X30 & PsENOD 3 and 14, PsNOD6 & This study \\
\hline
\end{tabular}

${ }^{a}$ and used for cDNA-cDNA hybridizations (Fig. 1).

$\mathrm{b}$ in accordance to Perlick and Pühler (1993). 
different leghemoglobins, transcripts homologous to the PSENOD2 (van de Wiel et al. 1990), PsENOD5 (Scheres et al. 1990) and PsENOD12 genes (Scheres et al. 1990) were isolated (Perlick and Pühler 1993). We also detected the recently described VfENOD-GRP3 (Küster et al. 1995), one of at least five nodule-specifically expressed broad bean genes encoding glycine-rich proteins (GRPs), VfNOD28/32 the homologue of MsNOD25 (Küster et al. 1994) and VfNOD32 encoding a narbonin-like nodulin with homologies to chitinases (Perlick et al. 1996). We further identified five groups of clones representing different members of a small gene family coding for nodulins with conserved cysteine clusters (CCPs) similar to the pea nodulin genes PsENOD3, PsENOD14 (Scheres et al. 1990), and PsNOD6 (Kardailsky et al. 1993).

\section{Detection of leghemoglobin $\mathrm{VfLb} 29$ transcripts in mycorrhizal roots.}

To investigate whether the identified nodulin genes are also induced in arbuscular mycorrhiza, we carried out stringent

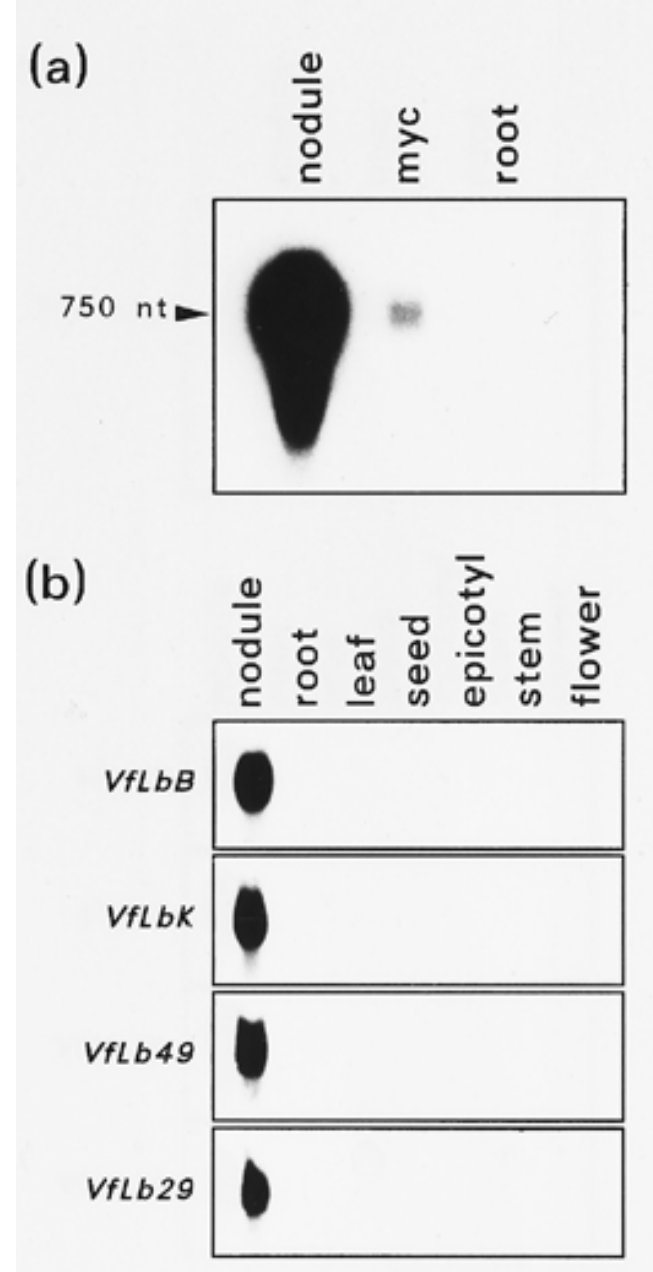

Fig. 2. Expression of broad bean leghemoglobin genes in different tissues. A, A Northern blot containing total RNA from nodules $(20 \mu \mathrm{g})$, mycorrhizal roots (myc; $40 \mu \mathrm{g}$ ) and uninfected roots $(40 \mu \mathrm{g})$ was hybridized against a $V f L b 29$ probe. The size of hybridizing transcripts calculated using RNA distance markers is indicated. B, Northern blots containing $30 \mu \mathrm{g}$ of total RNA from nodules, uninfected roots, leaves, seeds, epicotyls, stems and flowers, hybridized against different leghemoglobin probes. Abbreviation: nt, nucleotides.
cDNA-cDNA hybridizations. This technique enables the expression analysis of several genes in a selected tissue just in one experiment. Twenty cDNA sequences representing the different nodule-specifically expressed broad bean genes (Table 1) were hybridized with radioactively labeled cDNA probes. As a control, a broad bean transcript sequence coding for ubiquitin was included (Fig. 1). The probes were synthesized from poly $(\mathrm{A})^{+}$RNA isolated either from broad bean root nodules, uninfected roots or roots colonized by the mycorrhizal fungus $G$. fasciculatum. The mycorrhizal infection was in the exponential phase of development within the roots, characterized by active proliferation of the intraradical mycelium (29.7\% colonised cortex) with intercellular hyphae and formation of intracellular haustorial arbuscules in parenchyma cells of $27.2 \%$ of the root system.

As expected, all cDNA sequences were detected by the nodule probe. The root cDNA probe exclusively hybridized with the ubiquitin cDNA indicating that this tissue was sterile with respect to Rhizobium. These results correspond to Northern blot hybridizations (Fig. 2). In comparison to the root probe, the mycorrhizal probe additionally hybridized with one out of the four different leghemoglobin transcript sequences, VfLb29. Even after overexposure and by analyzing several filters with independent cDNA probes the observed hybridization patterns were always the same (data not shown).

However, Northern blot hybridizations were carried out in order to confirm the VfLb29 expression in mycorrhizal roots. The VfLb29 probe detected a transcript in nodules and in lower amounts in mycorrhizal roots. The hybridizing transcripts were of the same size in both tissues (Fig. 2A). Analysis of nodules, uninfected roots, leaves, seeds, epicotyls, stems, and flowers showed expression of the leghemoglobin genes VfLbB, VfLbK, VfLb49 and VfLb29 only in the nodule tissue (Fig. 2B).

Since the knowledge of fungal gene expression in planta is limited, it is possible that the hybridization of the VfLb29 cDNA with RNA isolated from mycorrhizal broad bean roots (Fig. 1 and Fig. 2A) was due to cross-hybridization with homologous transcripts of fungal origin. This was ruled out by the isolation and sequencing of a 139-bp VfLb29 RACE fragment, which was amplified from mycorrhizal broad bean roots. This fragment was identical to the $5^{\prime}$-end of the VfLb29 transcript sequence presented in Figure 3, indicating the plant origin of the hybridizing transcripts and confirming the presence of this plant leghemoglobin transcript in mycorrhizal roots.

\section{VfLb29 is an unusual member of the broad bean leghemoglobin family.}

Isolated cDNA clones representing the four different leghemoglobin groups were subjected to restriction mapping. To

Table 2. Comparison of four broad bean leghemoglobins ${ }^{\mathrm{a}}$

\begin{tabular}{|c|c|c|c|c|c|c|c|}
\hline \multirow{2}{*}{$\begin{array}{l}\text { Broad bean } \\
\text { leghemoglobin }\end{array}$} & \multicolumn{2}{|c|}{$\begin{array}{l}\text { Protein } \\
\text { size in }\end{array}$} & \multirow{2}{*}{$\begin{array}{c}\text { Calculated } \\
\text { pI }\end{array}$} & \multicolumn{4}{|c|}{$\begin{array}{c}\text { Amino acid sequence } \\
\text { identity to }(\%)\end{array}$} \\
\hline & $\mathbf{a a}$ & kDa & & VfLbK & VfLbK & VfLb49 & VfLb29 \\
\hline VfLbB & 147 & 15.8 & 7.7 & / & 80.3 & 81.0 & 61.5 \\
\hline VfLbK & 146 & 15.9 & 5.9 & 80.3 & I & 84.9 & 65.5 \\
\hline VfLb49 & 146 & 15.9 & 5.9 & 81.0 & 84.9 & / & 67.6 \\
\hline VfLb29 & 148 & 16.5 & 4.7 & 61.5 & 65.5 & 67.6 & I \\
\hline
\end{tabular}

${ }^{a}$ Abbreviations: aa, amino acids; kDa, kilodaltons; $\mathrm{pI}$, isoelectric point. 
determine the complete coding regions the longest cDNAs 150-1 (VfLbB), 111-51 (VfLbK), lb49 (VfLb49) and 257-1 (VfLb29) were sequenced (Fig. 3). Based on sequence similarities to leghemoglobins from other legumes, the $V f L b B$, $V f L b K$ and $V f L b 49$ clones were identified as full-length cDNAs. Since the clone 257-1 did not extend to the 5'untranslated transcript region the RACE-PCR technique was used to complete the cDNA. The VfLb29 RACE fragment amplified from root nodule RNA was 219 bp in length, overlapping 160 identical base pairs of the corresponding cDNA clone $257-1$. Whereas the sequence of $1 \mathrm{~b} 49$ was terminated by a poly(A) tail, the other cDNAs lacked this feature. This absence was also observed in further sequenced leghemoglobin clones of the cDNA library and could be explained by an incomplete second-strand cDNA synthesis. One possible poly(A) site could be identified with another VfLb29 clone 226-1, which was identical for 459 base pairs with the cDNA clone 257-1. The parts of the VfLb29 sequence completed by

\section{$V f L b B$}

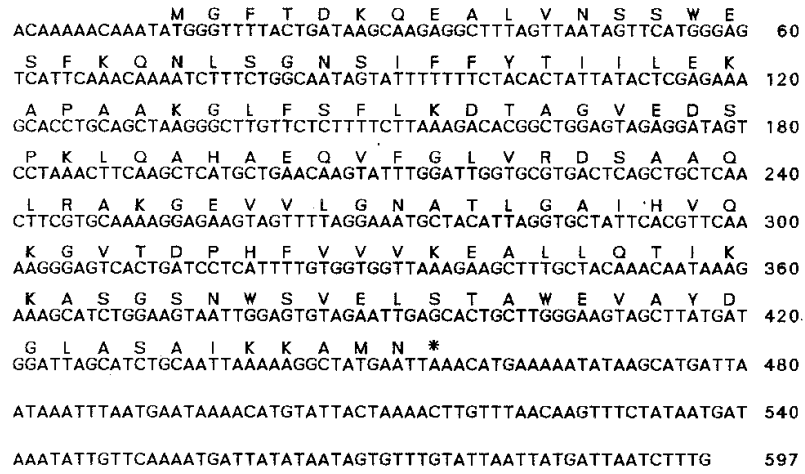

\section{$V f L b 49$}

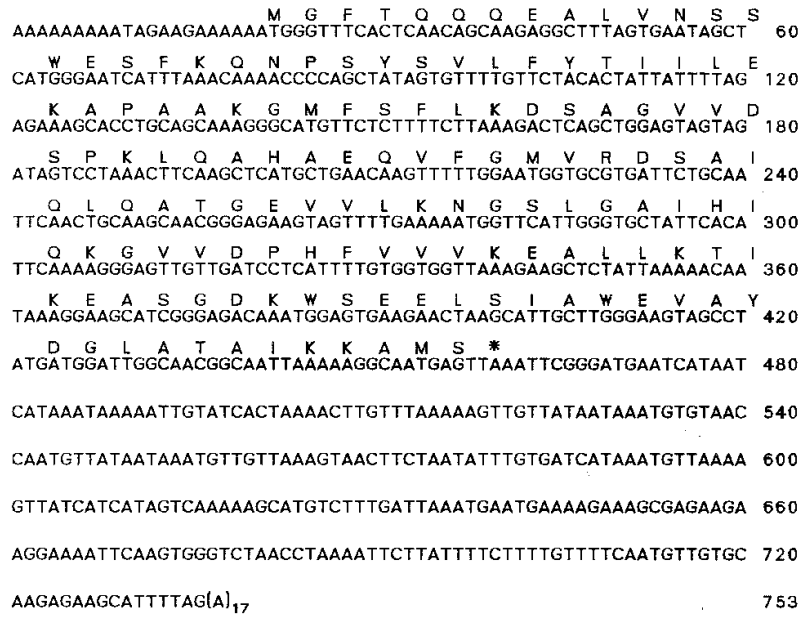

RACE fragments and the cDNA clone 226-1 are underlined in Figure 3.

The molecular masses of the specified leghemoglobins range from $15.8 \mathrm{kDa}$ for the $\mathrm{VfLbB}$ up to $16.5 \mathrm{kDa}$ for the acidic VfLb29 (Table 2). An alignment of the deduced amino acid sequences is shown in Figure 4A. Whereas the VfLbB, VfLbK, and VfLb49 sequences showed an identity of over $80 \%$ between each other, the VfLb29 sequence differed from these leghemoglobins by 32 to $38 \%$ at the amino acid level. Database searches revealed no higher homologies to VfLb29 for other (leg)hemoglobins. Figure 4B presents an alignment dendrogram based on amino acid identities which reflects the relationship between plant (leg)hemoglobins and the outstanding position of VfLb29 among the broad bean leghemoglobins. However, residues conserved between known plant and animal hemoglobins (Arredondo-Peter and Escamilla 1991) were also found to be conserved in all broad bean leghemoglobins (marked in Fig. 4). On the other hand, three of

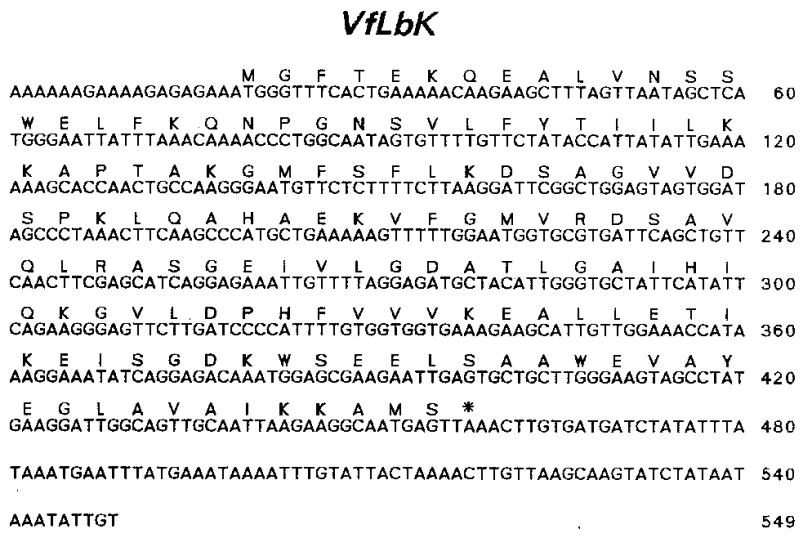

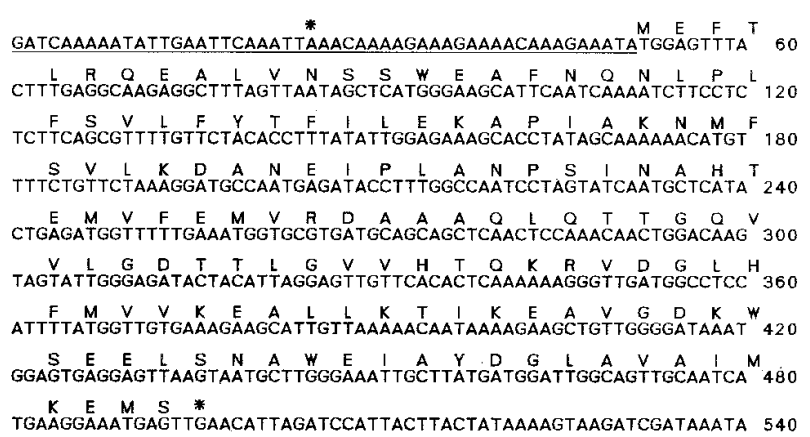

AAATTTATTTTCCTAAAATTTTAATTAAGTTTTTTAATAAATGTTGTTGAAACTAATTCG BOO

TTAAGAACCTTTGAGgTATACCCTCAATATGTTTGTATAATAAGTTATTTTAAATTTGAA 660 TtTGAaGTTTTATTTCAATACTAAGAGTTTATGTATTTGTACTTCAAGAGACATACTTTA 720 TATTTTTTC(A)

735

Fig. 3. Nucleotide and deduced amino acid sequence of broad bean leghemoglobin cDNAs. The nucleotide sequences of the cDNA clones 150-1 (encoding VfLbB), 111-51 (encoding VfLbK), lb49 (encoding VfLb49) and 257-1 (encoding VfLb29) are presented. The VfLb29 5'-sequence completed by RACE-PCR and the 3'-untranslated sequence completed by the cDNA clone 226-1 are underlined. Deduced amino acid sequences are indicated above the nucleotide sequences. The length of poly(A) tails is indicated. Stop codons are marked by asterisks. 
the amino acid residues conserved among leghemoglobins (Arredondo-Peter and Escamilla 1991) changed in the VfLb29 protein sequence. Two of these exchanges are conservative (Ile-60 and Thr-64 replace Leu and Ala, respectively), whereas Lys in position 144 changed to Met.

\section{DISCUSSION}

The expression of 20 different broad bean genes encoding early and late nodulins was analyzed in broad bean roots colonized by the arbuscular mycorrhizal fungus G. fasciculatum. Only the leghemoglobin gene VfLb29 was found to be induced

\begin{abstract}
A)
VFLbB MGFTDKOEALVNSSWESFKQNLSGNSI FFYTI I LEKAPAAKGLFSFLKDTAG

VFLbK MGFTEKOEALVNSSWELFKONP-GNSVLFYTI I LKKAPTAKGMFSSLKDSAG

VfL 449 MGFTQQOEALVNSSWESFKONP - SYSVLFYT I I LEKAPAAKGMFISF LKDSAG

VfLb29 MEFTLROEALVNSSWEAFNQNLPLFSVLFYTF I LEKAP I AKNMESVLKDANE

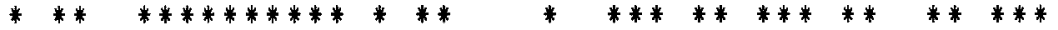

VfLbB VEDS-PKLQAHAEOVFGLVRDSAAQLRAKGEVVLGNAT L GAI HVQKGVTDPH

VFLbK VVDS-PKLQAHAEKVFGMVRDSAVQLRASGE IVLGDATLGAI HIOKGVLDPH

VfLb49 VVDS-PKL QAHAEQVFGMVRDSA I QLLOATGEVVLKNGSL GAI H I OKGVVDPH

VfLb29 I PLANPS I NAHTEMVFEMVRDAAAQLLTTGOVVLGDTT LGVVHTOKRVDGLH * $* * * * * * * * * * * * \quad * \quad * * \quad * * * * * * * *$

VfLbB FVVVKEALLQTIKKASGSNWSVELSTAWEVAYDGLASAIKKAMN 147:aa VfLbK FVVVKEALLETIKEISGDKWSEELSAAWEVAYEGLAVAIKKAMS 146 aa VfLb49 FVVVKEALLKTIKEASGDKWSEELSI AWEVAYDGLATA I KKAMS - 146 aa VfLb29 EMVVKEALLKTIKEAVGDKWSEEL SNAWE I AYDGL AVA IMKEMS 148 aа
\end{abstract}

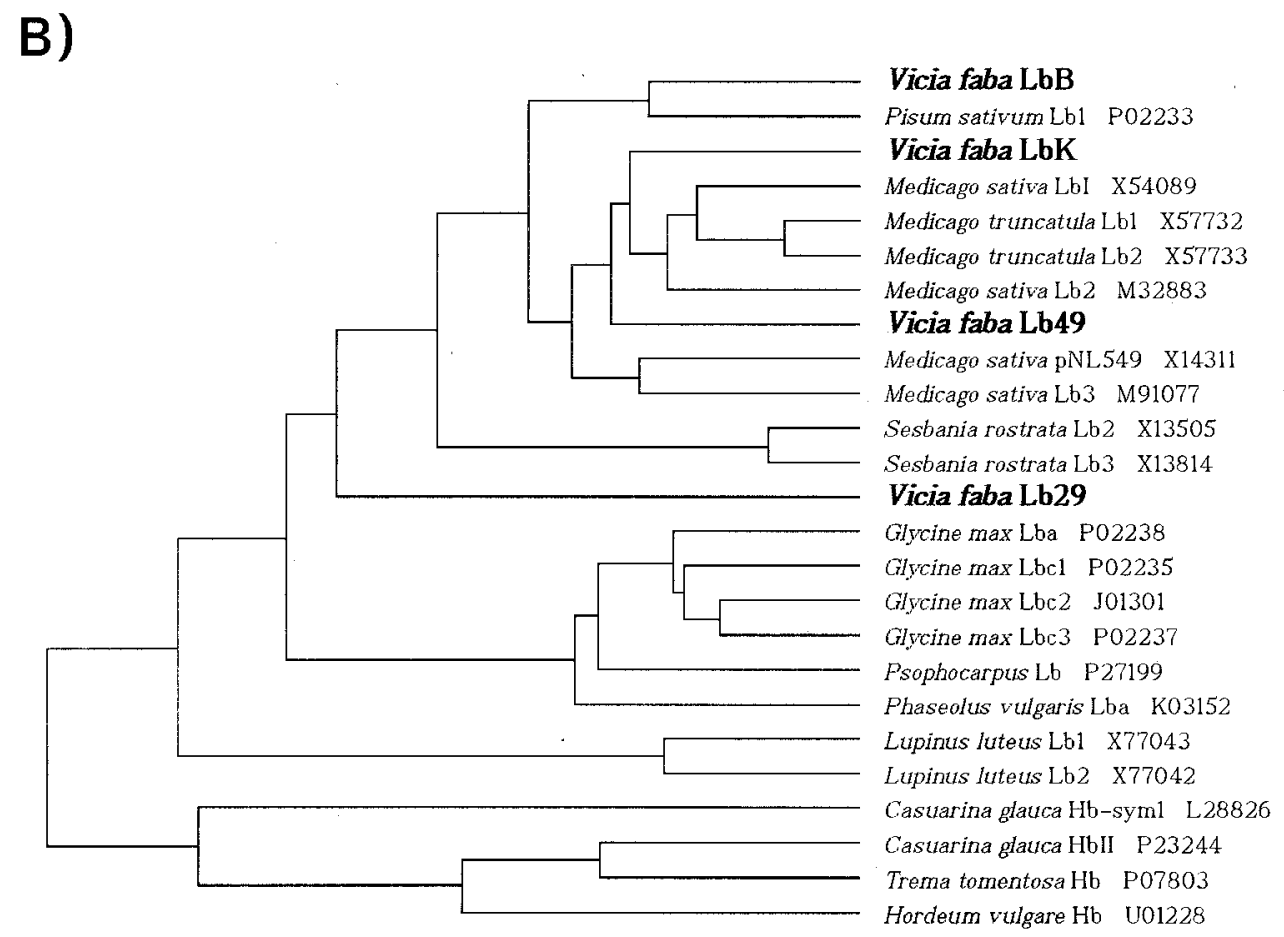

Fig. 4. Sequence comparison of plant (leg)hemoglobins. A, Alignment of the deduced amino acid sequences of VfLbB, VfLbK, VfLb49, and VfLb29. Identical residues in all four sequences are indicated by asterisks. Residues conserved between plant and animal hemoglobins are boxed. B, Unrooted dendrogram of the alignment from 25 plant (leg)hemoglobin protein sequences. The database accession numbers are indicated after the (leg)hemoglobin names. Abbreviations: aa, amino acids; Lb, leghemoglobin; Hb, hemoglobin. 
in mycorrhizal roots, whereas all other nodulin transcripts tested, including other leghemoglobin transcripts, could not be detected. In particular, we were unable to show a mycorrhizainduced expression of the early nodulin genes VfENOD5 and VFENOD12. These results are in accordance with preliminary findings for pea where PSENOD5 and PSENOD12 transcripts (Scheres et al. 1990) could not be detected during arbuscular mycorrhizal infection by in situ hybridizations (Gollotte et al. 1993). To our knowledge homologues of the other broadbean nodulin genes tested have not been analyzed for their expression in mycorrhizal roots until now. It cannot be excluded that the abscence of detection of early nodulin gene expression may have been linked to a low frequency of early infection stages (appressoria and first intercellular hyphae) which were present in less than $3 \%$ of the root system. This will have favored the detection of later infection events. However, the present results suggest that the large majority of the broad bean nodulins analyzed seem to play no role during the exponential phase of development within the arbuscular mycorrhiza symbiosis. On the other hand, the results of Wyss et al. (1990) indicate the presence of at least five different nodulins in mycorrhizal soybean roots, one of which may be related to nodulin 26 . Therefore the existence of yet unidentified broad bean genes specifically activated in both symbiotic tissues cannot be excluded.

Northern blot experiments confirmed that the leghemoglobins VfLbB, VfLbK, and VfLb49 are exclusively expressed in root nodules whereas VfLb29 is additionally induced in mycorrhizal roots. The different signal intensities for nodules and mycorrhizal roots do not necessarily indicate a low expression level of VfLb29 during mycorrhiza, since this gene might be expressed only in a limited number of cells within the mycorrhizal roots. The role of leghemoglobin as an oxygen carrier and facilitator of oxygen diffusion in legume nodules has been well documented (Appleby 1984; Layzell and Hunt 1990). In recent years, plant hemoglobins have also been identified in several non-legumes where they were found to be expressed in different tissues (e.g., Landsmann et al. 1986; Bogusz et al. 1988; Christensen et al. 1991; Taylor et al. 1994). Alternative functions, e.g., as oxygen sensors, have been suggested for nonsymbiotic plant hemoglobins (Appleby et al. 1988), and it has recently been reported that a barley hemoglobin gene is induced by hypoxic conditions (Taylor et al. 1994) supporting the oxygen transport role. Therefore, a possible function of the leghemoglobin in mycorrhizal roots could be to assure an oxygen supply for respiration of the microsymbiont, as in root nodules. Localization of the leghemoglobin VfLb29 gene products in root cells infected by arbuscular mycorrhizal fungi by in situ hybridization or immunocytochemistry would lead support to this hypothesis. However, to demonstrate the symbiotic-specific nature of VfLb29 expression in mycorrhiza, it will be necessary to prove that the VfLb29 gene is induced by the fungus itself and not within the framework of an anaerobic response in infected roots.

Considering its unique expression pattern it is interesting to note that the leghemoglobin VfLb29 is characterized by a relative low level of sequence identity compared to the other broad bean leghemoglobins. Whereas the sequence divergency between VfLbB, VfLbK, and VfLb49 at the amino acid level does not exceed $20 \%$, the VfLb29 sequence differs from these leghemoglobins by 32 to $38 \%$. The outstanding characteristics of VfLb29 within the broad bean leghemoglobin family resemble the differences between symbiotic and nonsymbiotic hemoglobins in the non-legume plant Casuarina glauca. The $\mathrm{CaHb}$-syml gene is exclusively expressed in nodules, whereas the $C a H b I I$ transcript could be detected in a number of different tissues, where oxygen supply is likely to be limited (Christensen et al. 1991; Jacobsen-Lyon et al. 1995). These hemoglobins show an amino acid identity of only 53\%, indicating their distant relation. In contrast to $\mathrm{CaHbII}$, in nodulated plants VfLb29 is exclusively expressed in nodules but it is also induced in roots when colonized by a mycorrhizal fungus. Moreover, the VfLb29 gene product, as is typical for symbiotic hemoglobins, lacks the N-terminal amino acid extension which is present in nonsymbiotic hemoglobins. The existence and role of leghemoglobins in tissues other than nodules have been speculated earlier (Appleby et al. 1988; Bogusz et al. 1988) and were supported by experiments of Jacobsen-Lyon et al. (1995). The authors demonstrated that the Casuarina hemoglobin gene CaHbII maintains its nonsymbiotic expression pattern even in the legume Lotus corniculatus.

In conclusion, VfLb29 appears to represent a new class of leghemoglobin genes not identified until now which are inducible in different symbiotic associations, whereas $V f L b B$, $V f L b K$, and $V f L b 49$ belong to the well-established group of nodule-specific leghemoglobin genes. Taking into account the ancestral nature of arbuscular mycorrhiza (Remy et al. 1994), it has been speculated that some plant processes involved in nodulation may have evolved from those already established for mycorrhiza (Gianinazzi-Pearson et al. 1994; Gollotte et al. 1995). The identification of the mycorrhiza induced broad bean leghemoglobin VfLb29 lends support to this hypothesis. Further investigations are necessary to determine whether mycorrhiza-induced (leg)hemoglobin genes exist in other legumes or even non-legumes.

\section{MATERIALS AND METHODS}

\section{Biological material and cDNA libraries.}

Broad bean plants (Vicia faba L. cv. Kleine Thüringer) were grown in the greenhouse in sterile clay granules (Seramis) using surface-sterilized seeds (saturated Ca-hypochlorite, 30 min). Nodulated plants were obtained by inoculation of 2 dayold seedlings with Rhizobium leguminosarum bv. viciae VF39 (Priefer 1989) and mycorrhizal plants by inoculation at transplanting into sterile soil (clay loam, pH 7.5, 23 ppm Olsen P) with Glomus fasciculatum (Thaxter sensu Gerdeman) Gerd and Trappe amend Walker and Koske (isolate LPA 7), using surface sterilized (1\% Chloramine T, 2 min) leek root inoculum placed in the planting hole. Uninoculated plants served as controls. To avoid contamination from Rhizobium, mycorrhizal and control plants were grown in individual Sunbags (Sigma) in a constant environment chamber ( $16 \mathrm{~h}$ day, $330 \mu \mathrm{mol}$ $\mathrm{s}^{-1} \mathrm{~m}^{-2}, 19 / 22^{\circ} \mathrm{C}$ ). Flowers and seeds were analyzed from fieldgrown plants. The nodule-specific cDNA library was constructed in $\lambda$ gt11 from poly $(\mathrm{A})^{+}$mRNA isolated from root nodules of $\mathrm{Vi}$ cia faba L. cv. Kleine Thüringer (Perlick and Pühler 1993).

\section{Isolation of nucleic acids and recombinant DNA techniques.}

Isolation of recombinant $\lambda$ gt11 DNA was carried out using standard protocols (Sambrook et al. 1989). Plasmid DNA was 
isolated from E. coli JM83 using the "Plasmid Midi Kit" (Qiagen) according to the manufacturer's instructions. Probe DNA was extracted from agarose gels using the "QIAEX Gel Extraction Kit" (Qiagen). For Northern blotting, total RNA was isolated from nodules (32 days after sowing), mycorrhizal roots ( 25 days after sowing), uninfected roots (25 and 32 days after sowing), leaves (32 days after sowing), seeds (90 days after sowing), epicotyls (8 days after sowing), stems (12 days after sowing) and flowers (60 days after sowing) of broad beans using standard protocols (de Vries et al. 1982). Mycorrhiza colonization was estimated microscopically from random root samples taken prior to extraction using the method described by Trouvelot et al. (1986). Poly(A) ${ }^{+}$RNA fractions were isolated by one cycle of oligo(dT)-cellulose chromatography.

The "5'-AmpliFINDER RACE KIT" (Clontech) was used to obtain cDNA clones encoding the $\mathrm{N}$-terminal amino acids of VfLb29. The cDNA synthesis was carried out according to the manufacturer's instructions using the VfLb29 specific primer 5'-TCACTCCATTTATCCCCAACAGC-3'. Amplification of VfLb29 5' cDNA fragments was performed during 35 cycles of 45 -s denaturation at $94^{\circ} \mathrm{C}, 45$-s primer annealing at $54^{\circ} \mathrm{C}$ and 2 min elongation at $72^{\circ} \mathrm{C}$ using nested VfLb29 specific $3^{\prime}$ primers (5'-GGTATCTCATTGGCATCCTTTAG$3^{\prime}$ and 5'-TAGAACAAAACGCTGAAGA-3').

To generate overlapping sequencing clones, exonuclease III digestions were carried out using the "Double Stranded Nested Deletion Kit" (Pharmacia) according to the manufacturer's instructions. All other in vitro DNA manipulations were carried out using standard protocols (Sambrook et al. 1989).

\section{DNA sequencing and sequence analysis.}

Sequencing reactions have been carried out according to Zimmermann et al. (1990) using the "AutoRead Sequencing Kit" (Pharmacia). Sequencing gels were run on the "A.L.F. DNA Sequencer" (Pharmacia) using sequencing gel mixes of standard composition (Biozym Diagnostik GmbH). All sequences reported here were determined from both strands. Nucleic acid sequences were read using the "A.L.F. MANAGER V2.6" software (Pharmacia) and analyzed using the programme "ANALYSEQ" (Staden 1986) and "LFASTA" (based on Pearson and Lipman 1988). Multiple sequence alignments were carried out using the program "CLUSTAL" (Higgins and Sharp 1988) from the PC/Gene software package (IntelliGenetics, release 6.80).

\section{Northern blot hybridizations.}

Northern blotting and hybridizations were carried out as described previously (Perlick and Pühler 1993). About $50 \mathrm{ng}$ of probe DNA isolated from agarose gels were labeled with 50 $\mu \mathrm{Ci}$ of $\alpha^{32} \mathrm{P}$-dATP according to Feinberg and Vogelstein (1983). Stringent washes were carried out at room temperature using $2 \times \mathrm{SSC}, 0.1 \%(\mathrm{w} / \mathrm{v}) \mathrm{SDS}(5 \mathrm{~min})$ and at $68^{\circ} \mathrm{C}$ using 0.2 $\times \mathrm{SSC}, 0.1 \%(\mathrm{w} / \mathrm{v}) \mathrm{SDS}$ (twice for $30 \mathrm{~min}$ each).

\section{cDNA-cDNA hybridizations.}

For cDNA-cDNA hybridizations, $0.2 \mu \mathrm{g}$ of EcoRI digested DNA from different cDNA clones was separated electrophoretically and blotted onto Hybond-N nylon membranes (Amersham) using standard protocols (Sambrook et al. 1989).
First-strand cDNA probes were synthesized from $1 \mu \mathrm{g}$ of poly $(\mathrm{A})^{+}$RNA according to Gerard $(1988)$ in an assay buffer containing $50 \mathrm{mM}$ Tris- $\mathrm{HCl}, \mathrm{pH} 8.3,75 \mathrm{mM} \mathrm{KCl}, 12 \mathrm{mM}$ $\mathrm{MgCl}_{2}, 10 \mathrm{mM}$ DTT, $0.5 \mathrm{mM}$ dCTP, dGTP and dTTP each, $100 \mu \mathrm{Ci}\left(\alpha^{32} \mathrm{P}\right) \mathrm{dATP}$, unlabeled dATP to a final concentration of $11.5 \mu \mathrm{M}, 1 \mu \mathrm{g}$ oligo(dT) $)_{12-18}$ and 200 units SUPER Script reverse transcriptase $\mathrm{RNase} \mathrm{H}^{-}$(Gibco BRL) at $37^{\circ} \mathrm{C}$ for 60 min. RNA was hydrolyzed by 5 min incubation at $95^{\circ} \mathrm{C}$ with 1 vol $0.3 \mathrm{M} \mathrm{NaOH}, 30 \mathrm{mM}$ EDTA. The resulting singlestranded cDNA probe was neutralized with 0.5 vol $1 \mathrm{M}$ Tris$\mathrm{HCl} \mathrm{pH} 8.0$ and used immediately for hybridization. Filters were hybridized in a solution containing $50 \mathrm{mM}$ Na phosphate $\mathrm{pH} 7.0,5 \times \mathrm{SSC}, 0.1 \%(\mathrm{w} / \mathrm{v})$ lauroylsarcosin, $2 \%(\mathrm{w} / \mathrm{v})$ blocking reagent (Boehringer), 7\% (w/v) SDS and 50\% (v/v) formamide for $48 \mathrm{~h}$ at $42^{\circ} \mathrm{C}$. Stringent washes were carried out as described for Northern blot hybridizations.

\section{LITERATURE CITED}

Appleby, C. A. 1984. Leghemoglobin and Rhizobium respiration. Annu. Rev. Plant Physiol. 35:443-478.

Appleby, C. A., Bogusz, D., Dennis, E. S., and Peacock, W. J. 1988. A role for hemoglobin in all plant roots? Plant Cell Environ. 11:359367.

Arredondo-Peter, R., and Escamilla, E. 1991. A consensus sequence of plant hemoglobins. Plant Mol. Biol. Rep. 9:195-207.

Bogusz, D., Appleby, C. A., Landsmann, J., Dennis, E. S., Trinick, M. J., and Peacock, W. J. 1988. Functioning haemoglobin genes in nonnodulating plants. Nature 331:178-180.

Bradbury, S. M., Peterson, R. L., and Bowley, S. R. 1991. Interactions between three alfalfa nodulation genotypes and two Glomus species. New. Phytol. 119:115-120.

Brewin, N. J. 1991. Development of the legume root nodule. Annu. Rev. Cell Biol. 7:191-226.

Christensen, T., Dennis, E. S., Peacock, J. W., Landsmann, J., and Marcker, K. A. 1991. Hemoglobin genes in nonlegumes: Cloning and characterization of a Casuarina glauca hemoglobin gene. Plant Mol. Biol. 16:339-344.

Delauney, A. J., and Verma, D. P. S. 1988. Cloned nodulin genes for symbiotic nitrogen fixation. Plant Mol. Biol. Rep. 6:279-285.

de Vries, S. C., Springer, J., and Wessels, J. G. H. 1982. Diversity of abundant mRNA sequences and patterns of protein synthesis in etiolated and greened pea seedlings. Planta 156:129-135.

Duc, G., Trouvelot, A., Gianinazzi-Pearson, V., and Gianinazzi, S. 1989. First report of non-mycorrhizal plant mutants $\left(\mathrm{Myc}^{-}\right)$obtained in pea (Pisum sativum L.) and fababean (Vicia faba L.). Plant Sci. 60:215222

Feinberg, A. P., and Vogelstein, B. 1983. A technique for radiolabeling DNA restriction endonuclease fragments to high specific activity. Anal. Biochem. 132:6-13.

Fischer, H. M. 1994. Genetic regulation of nitrogen fixation in Rhizobia. Microbiol. Rev. 58:352-386.

Fisher, R. F., and Long, S. R. 1992. Rhizobium-plant signal exchange. Nature 357:655-660.

Gerard, G. F. 1988. Synthesis of high specific activity cDNA. FOCUS 10:12-13.

Gianinazzi-Pearson, V., Gianinazzi, S., and Brewin, N. J. 1990. Immunocytochemical localisation of antigenic sites in the perisymbiotic membrane of vesicular-arbuscular endomycorrhiza using monoclonal antibodies reacting against the peribacteroid membrane of nodules. Endocytobiology IV:127-131.

Gianinazzi-Pearson, V., Gianinazzi, S., Guillemin, J. P., Trouvelot, A., and Duc, G. 1991. Genetic and cellular analysis of resistance to vesicular-arbuscular (VA) mycorrhizal fungi in pea mutants. Pages 336342 in: Advances in Molecular Genetics of Plant-Microbe Interactions. Vol 1. H. Hennecke, and D. P. S. Verma, eds. Kluwer Academic Publishers, Dordrecht.

Gianinazzi-Pearson, V., Gollotte, A., Dumas-Gaudot, E., Franken, P., and Gianinazzi, S. 1994. Gene expression and molecular modifications associated with plant responses to infection by arbuscular my- 
corrhizal fungi. Pages 179-186 in: Advances in Molecular Genetics of Plant-Microbe Interactions. Vol. 3. M. J. Daniels, J. A. Downie, and A. E. Osbourn, eds. Kluwer Academic Publishers, Dordrecht.

Gollotte, A., Gianinazzi-Pearson, V., Giovannetti, M., Sbrana, C., Avio, L., and Gianinazzi, S. 1993. Cellular localization and cytochemical probing of resistance reactions to arbuscular mycorrhizal fungi in a 'locus $a$ ' myc' mutant of Pisum sativum L. Planta 191:112-122.

Gollotte, A., Gianinazzi-Pearson, V., and Gianinazzi, S. 1995. Immunodetection of infection thread glycoprotein and arabinogalactan protein in wild type Pisum sativum (L.) or an isogenic mycorrhizaresistant mutant interacting with Glomus mosseae. Symbiosis 18:6985.

Harley, J. L., and Smith, S. E. 1983. Mycorrhizal symbioses. Academic Press, London.

Higgins, D. G., and Sharp, P. M. 1988. CLUSTAL: A package for performing multiple sequence alignment on a microcomputer. Gene 73:237-244.

Jacobsen-Lyon, K., Jensen, E. Ø., Jørgensen, J.-E., Marcker, K. A., Peacock, W. J., and Dennis, E. S. 1995. Symbiotic and nonsymbiotic hemoglobin genes of Casuarina glauca. Plant Cell 7:213-223.

Kardailsky, I. V., Yang, W. C., Zalensky, A., van Kammen, A. and Bisseling, T. 1993. The pea late nodulin gene PsNOD6 is homologous to the early nodulin genes PsENOD3/14 and is expressed after the leghaemoglobin genes. Plant Mol. Biol. 23:1029-1037.

Küster, H., Perlick, A. M., and Pühler, A. 1994. Members of a broadbean nodulin family with partial homologies to the alfalfa nodulin 25 are composed of two types of amino acid repeats flanked by unique amino acid sequence termini. Plant Mol. Biol. 24:143-157.

Küster, H., Schröder, G., Frühling, M., Pich, U., Rieping, M., Schubert, I., Perlick, A. M., and Pühler, A. 1995. The nodule-specific VfENODGRP3 gene encoding a glycine-rich early nodulin is located on chromosome I of Vicia faba L. and is predominantly expressed in the interzone II-III of root nodules. Plant Mol. Biol. 28:405-421.

Landsmann, J., Dennis, E. S., Higgins, T. J. V., Appleby, C. A., Kortt, A. A., and Peacock, W. J. 1986. Common evolutionary origin of legume and non-legume plant haemoglobins. Nature 324:166-168.

Layzell, D. B., and Hunt, S. 1990. Oxygen and the regulation of nitrogen fixation in legume nodules. Physiol. Plant. 80:322-327.

Mellor, R. B. 1989. Bacteroids in the Rhizobium-legume symbiosis inhabit a plant internal lytic compartment: Implications for other microbial endosymbioses. J. Exp. Bot. 40:831-839.

Pearson, W. R., and Lipman, D. J. 1988. Improved tools for biological sequence comparison. Proc. Natl. Acad. Sci. USA 85:2444-2448.

Perlick, A. M., and Pühler, A. 1993. A survey of transcripts expressed specifically in root nodules of broadbean (Vicia faba L.). Plant Mol. Biol. 22:957-970.

Perlick, A. M., Frühling, M., Schröder, G., Frosch, S. C., and Pühler, A. 1996. The broad bean gene VfNOD32 encodes a nodulin with sequence similarities to chitinases that is homologous to $(\alpha / \beta)_{8}$-barreltype seed proteins. Plant Physiol. 110:147-154.

Perotto, S., VandenBosch, K. A., Brewin, N. J., Faccio, A., Knox, J. P., and Bonfante, P. 1989. Modifications of the host cell wall during root colonization by Rhizobia and VAM fungi. Pages 115-117 in: Endocytobiology. IV. P. Nardon, V. Gianinazzi-Pearson, A. M. Grenier, L. Margulis, and D. C. Smith, eds. INRA Press, Paris.

Perotto, S., Brewin, N. J., and Bonfante, P. 1994. Colonization of pea roots by the mycorrhizal fungus Glomus versiforme and by Rhizobium bacteria: Immunological comparison using monoclonal antibodies as probes for plant cell surface components. Mol. Plant-Microbe Interact. 7:91-98.

Priefer, U. B. 1989. Genes involved in lipopolysaccharide production and symbiosis are clustered on the chromosome of Rhizobium leguminosarum biovar viciae VF39. J. Bacteriol. 171:6161-6168.

Remy, W., Taylor, T. N., Hass, H., and Kerp, H. 1994. Four hundredmillion-year-old vesicular arbuscular mycorrhizae. Proc. Natl. Acad. Sci. USA 91:11841-11843.

Sambrook, J., Fritsch, E. F., and Maniatis, T. 1989. Molecular Cloning. A Laboratory Manual, 2nd ed. Cold Spring Harbor Laboratory Press, Cold Spring Harbor, New York.

Scheres, B., van Engelen, F., van der Knaap, E., van de Wiel, C., van Kammen, A., and Bisseling, T. 1990. Sequential induction of nodulin gene expression in the developing pea nodule. Plant Cell 2:687-700.

Smith, S. E., and Smith, F. A. 1990. Structure and function of the interface in biotrophic symbiosis as they relate to nutrient transport. New. Phytol. 114:1-38

Staden, R. 1986. The current status and probability of our sequence handling software. Nucleic Acids Res. 14:217-231.

Taylor, E. R., Nie, X. Z., MacGregor, A. W., and Hill, R. D. 1994. A cereal haemoglobin gene is expressed in seed and root tissues under anaerobic conditions. Plant Mol. Biol. 24:853-862.

Trouvelot, A., Kough, J. L., and Gianinazzi-Pearson, V. 1986. Mesure du taux de mycorhization VA d'un système radiculaire. Recherche de méthodes d'estimation ayant une signification fonctionnelle. Pages 217-221 in: Physiological and Genetical Aspects of Mycorrhizae V. Gianinazzi-Pearson, and S. Gianinazzi, eds. INRA-Press, Paris.

VandenBosch, K. A., Bradley, D. J., Knox, J. P., Perotto, S., Butcher, G. W., and Brewin, N. J. 1989. Common components of the infection thread matrix and the intercellular space identified by immunocytochemical analysis of pea nodules and uninfected roots. EMBO J. 8:335-342.

van de Wiel, C., Scheres, B., Franssen, H., van Lierop, M.-J., van Lammeren, A., van Kammen, A., and Bisseling, T. 1990. The early nodulin transcript ENOD2 is located in the nodule parenchyma (inner cortex) of pea and soybean root nodules. EMBO J. 9:1-7.

van Kammen, A. 1984. Suggested nomenclature for plant genes involved in nodulation and symbiosis. Plant Mol. Biol. Rep. 2:43-45.

Verma, D. P. S., Hu, C.-A., and Zhang, M. 1992. Root nodule development: origin, function and regulation of nodulin genes. Physiol. Plant. 85:253-265.

Weeden, N. F., Kneen, B. E., and Larue, T. A. 1990. Map position of sym genes involved in nodulation and nitrogen fixation in Pisum sativum. Page 323 in: Nitrogen fixation: achievements and objectives. P. M. Gresshoff, L. E. Roth, G. Stacey, and W. E. Newton, eds. Chapman and Hall, New York.

Wyss, P., Mellor, R. B., and Wiemken, A. 1990. Vesicular-arbuscular mycorrhizas of wild-type soybean and non-nodulating mutants with Glomus mosseae contain symbiosis-specific polypeptides (mycorrhizins), immunologically cross-reactive with nodulins. Planta 182:22-26.

Zimmermann, J., Voss, H., Schwager, C., Stegemann, J., Erfle, H., Stucky, K., Kristensen, T. and Ansorge, W. 1990. A simplified protocol for fast plasmid DNA sequencing. Nucleic Acids Res. 18:1067. 